\title{
Vulnerability of Farm Households to Impacts of the Abaca Bunchy Top Disease: A Case in Leyte, Philippines
}

\author{
Jedess Miladel N. Salomon
}

\begin{abstract}
The abaca bunchy top disease (ABTD) has destroyed thousands of hectares of abaca farms, leading to the decline in agriculture and economic production of farmers and their households. This paper frames the widespread disease incidence as a disaster and analyzes the factors that made farm households in Barangay Pinamonoan, an abaca-growing community, vulnerable to the disease and its impacts. It grounds its analysis on the pressure and release (PAR) and access models by Blaikie et al (1994) and the sustainable livelihoods framework by Scoones $(1998,2009)$. From these, an analytical framework was developed to illustrate the complexity of the relationships of the different factors contributing to farm households' vulnerability to a widespread crop disease.

The reliance of farm households on abaca production was influenced by the high global demand of abaca fiber. This global demand made abaca an important export commodity; hence, government policies and programs were focused on increasing its production and less on ensuring that the livelihoods of farm households were secure. While abaca production is profitable, sole reliance on this could prove disastrous in the event of a hazard. Access to resources determined how farm households absorbed the shock and recovered from it. Households who had significant assets were able to shift to other crops or enterprises. Households with access to people with resources and who could provide assistance were also more likely to cope. The most affected in the village were the households who, even before the disease, had limited resources, both in terms of material assets and social support networks.
\end{abstract}

Keywords: sustainable livelihoods, assets, crop disease, disaster

\section{INTRODUCTION}

Most of the residents of Barangay village Pinamonaon, Mahaplag, Leyte are farmers whose main income source was abaca production until the abaca bunchy top disease (ABTD) struck in the late 1990s and early 2000s. ABTD is caused by the

National Abaca Research Center, Visayas State University, Visca, Baybay City, Leyte 6521-A, Philippines

*Corresponding Author. Address: National Abaca Research Center, Visayas State University, Visca, Baybay City, Leyte 6521-A, Philippines. E-mail:jedess.salomon@vsu.edu.ph Tel No. (053) 563-7598 DOI: $10.32945 / \operatorname{atr} 39210.2017$ 
Vulnerability of farm households to impacts of the abaca bunchy top disease

abaca bunchy top virus (ABTV) carried by the brown aphid Pentalonia nigronervosa. Infected crops exhibit discoloration of leaves from green to orange or yellow, bunching of leaves, and stunted growth (Figure 1). Therefore, infected plants cannot be harvested. The infection reached alarming rates in the provinces of Leyte and Samar, both large producers of abaca fiber, when the disease reportedly wiped out 16,737 ha of a total of 26,374 hectares of abaca plantations (Manila Bulletin 2003).

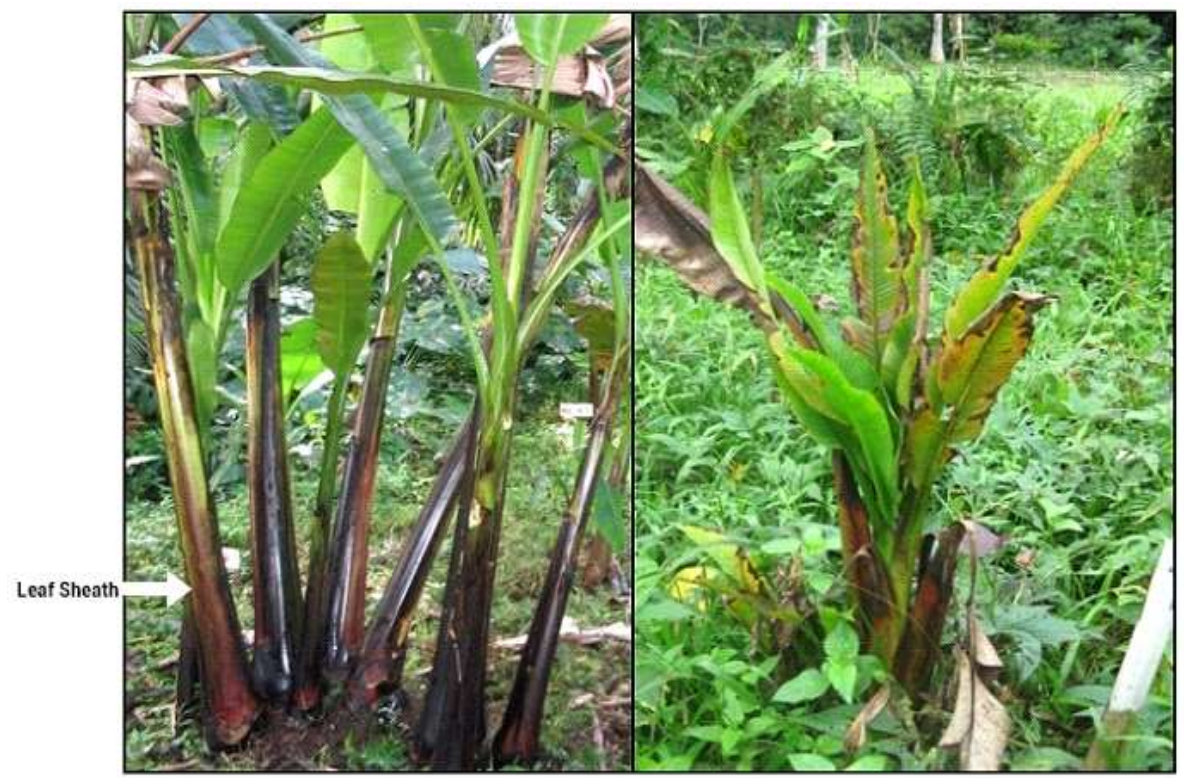

Figure 1. Healthy abaca Suckers (Left picture) and abaca with ABTD (right picture)

The widespread incidence of a crop disease in an economically challenged community can be seen as a disaster in that it is 'a process/event involving a combination of a potentially destructive agents from the natural and/or technological environment and a population in a socially and technologically produced condition of environmental vulnerability' (Oliver-Smith 1996:305). This vulnerability does not result from exposure to the hazard, but is pre-existing in daily life and becomes apparent through exposure to the hazard (Cannon 2000). Looking at ABTD as a biological hazard and the widespread disease incidence as a 'disaster' (Blaikie et al 1994), this study applies this notion to examine economic, social, and political factors which may have contributed to the vulnerability of farm households in Brgy. Pinamonoan to ABTD. It assesses how farm households' access profiles, farm practices and the agricultural extension system operating in the area have contributed to people's vulnerability. Households' access to resources determines the range of income opportunities they could harness and their resilience in adverse circumstances (Blaikie et al 1994). Farm practices and extension are important factors in farm productivity and the resilience of agricultural livelihoods in times of stress and shocks. 
According to Blaikie et al (1994:9), vulnerability involves 'a combination of factors that determine the degree to which someone's life and livelihood is put at risk by a discrete and identifiable event in nature and society.' Clark et al (1998:59) defines it as 'people's incapacity to deal with hazards, based on the position of groups and individuals within the physical and social world.' It is the function of both exposure to a hazard and coping ability. This study concurs with the proposition that disasters are not caused by hazards alone, but are the result of a vulnerable population's response to a hazard (Blaikie et al 1994). Farmers in developing countries are known to be vulnerable to crop disease, given their lack of access to technologically advanced diagnostics, agronomic practices, and disease management strategies (Vurro et al 2010).

However, studies on crop diseases do not consider the issue of vulnerability who is affected and why. Grounded on the PAR and access models of Blaikie et al (1994), and Scoones' $(1998,2009)$ sustainable rural livelihoods framework, this study analyzed a lesser studied area of this unfolding 'disaster', that is, a farming household's vulnerability. This brings attention to the importance of agriculture in the livelihoods and economies of developing countries such as the Philippines and contributes to the development of more appropriate policies and programs to address and integrate the needs of farming households.

\section{MATERIALS AND METHODS}

This case study was conducted in Pinamonoan, one of the 28 barangays of the municipality of Mahaplag (Figure 2). It was selected as the study site for the following reasons: 1) most, if not all, of the residents were abaca farmers before the disease incidence; 2 ) the great extent of damage by ABTD to their farms; and 3 ) the relative accessibility of the village compared to other abaca-producing villages considered. At the time of the 2000 census, Brgy. Pinamonoan had a population of 1101 distributed among 185 households (National Statistics Office 2000). The village has a total land area of $938.12 \mathrm{ha}, 332$.6ha of which is planted with abaca.

Information on the occurrence of ABTD, its impacts and the adaptive strategies of farm households was gathered from 20 January to 14 February 2011 through semi-structured interviews with 38 household heads and members of 32 households who cultivated abaca (currently or formerly) were interviewed. They were classified according to the area of land they owned: $<10 \mathrm{ha}-$ small landowner, 10-30ha - medium landowner (Food and Agriculture Organization 2003). The household was the unit of analysis because it was assumed that decisions about production, investment, consumption and the mobilization of resources and assets were taken primarily at the household level (Blaikie et al 1994, Corbett 1988).

The interview guide was designed to gather information on the respondents' personal details, land and assets, and livelihood. It assessed their experiences with abaca farming, the occurrence of ABTD on their farms, its impacts, the adaptive strategies they employed and the assistance they received from government and non-government organizations. Focus group discussions involving male and female farmers were also conducted to confirm the information gathered in the interviews and to gather additional information. 
Vulnerability of farm households to impacts of the abaca bunchy top disease

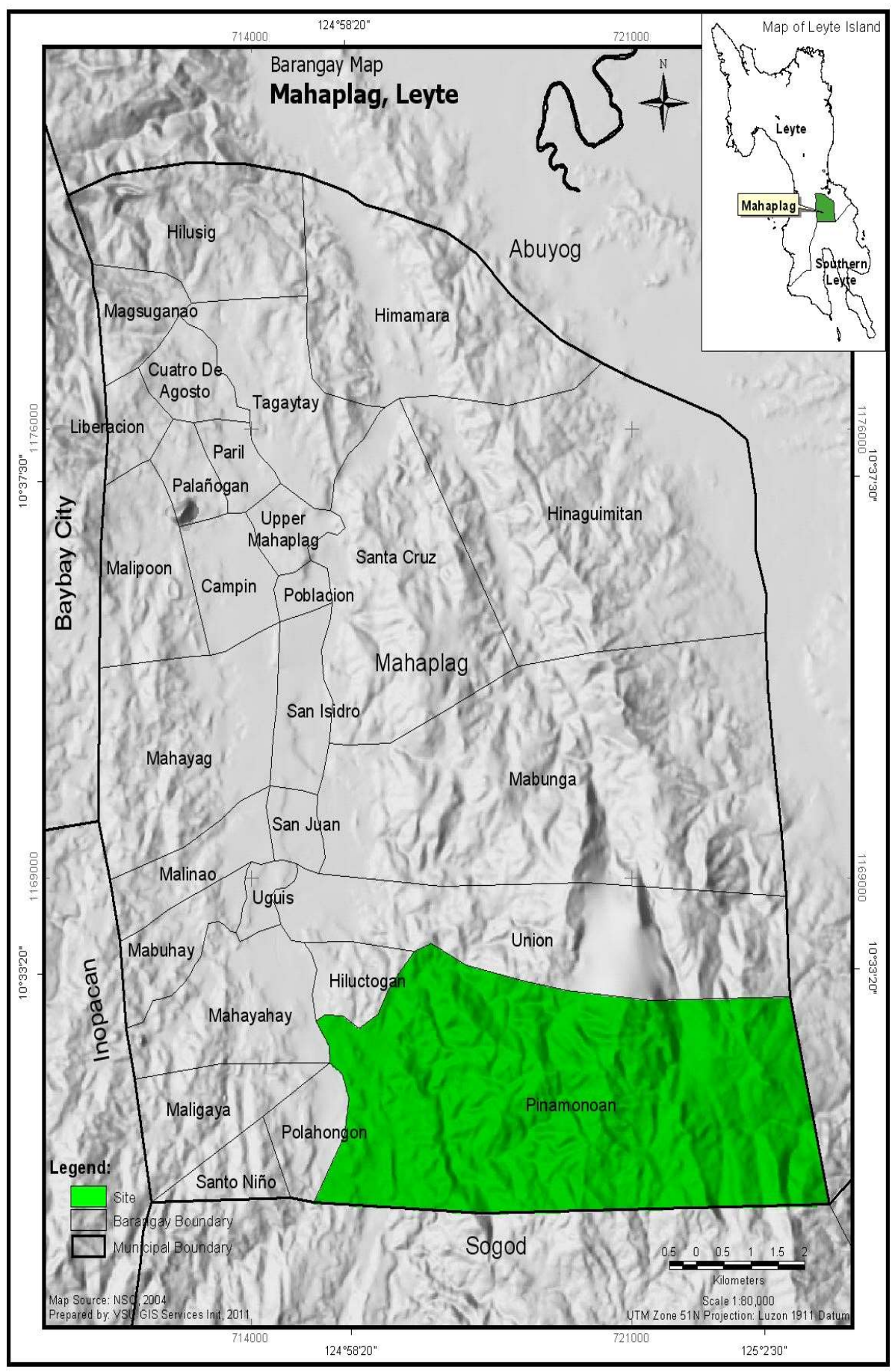

Figure 2. Map of the study site: Brgy. Pinamonaon, Mahaplag, Leyte Source: Ecological Farm and Resource Management Institute (2011) 
Key informants were also interviewed: extension agents from three different government agencies concerned with the abaca industry, the councilor who was the chairman for agriculture in the municipality during the time of the widespread occurrence of the disease, and the current and former barangay captains of Pinamonoan. The interviews were designed to gather information on the situation of abaca production before and after ABTD, the changes they observed in the lives of the affected farmers and their households, the assistance they received and the challenges met in conducting eradication and assistance programs in the village.

The use of both the PAR and access models enabled the researches to analyze households and their vulnerability in terms of their access to resources and to relate this to the global and political dynamics/processes that influence this access. By supplementing the access model with the sustainable livelihoods framework, resources were classified into specific types of capital. This allowed a detailed assessment of how access to different types of capital influence farm households' livelihood strategies before ABTD and adaptive strategies used after occurrence of the disease.

The PAR model shows how disaster occurs when a hazard, an extreme natural event, affects vulnerable people. It shows disaster as the intersection of two opposing forces: the underlying processes that generate vulnerability on one side, and the exposure to a hazard on the other. Affected people are caught in the middle with increasing pressure from both sides.

The access model addresses the PAR model's limitation of considering the hazard as separate from the social processes that influence vulnerability by recognizing that hazards reinforce vulnerability by changing people's access to resources, thus influencing their ability to recover. Access to resources is determined by social and economic relations such as status, gender and race. Thus, there is inequality among people or groups of people which makes some less or more vulnerable than others. People with better access to resources are less likely to suffer the impacts of a hazard and are more likely to cope (Blaikie et al 1994).

The sustainable livelihoods framework (Scoones 1998, 2009) uses similar concepts around the notion of access to assets. In this framework, a sustainable livelihood is one that can 'cope with and recover from stresses and shocks, maintain or enhance its capabilities and assets, while not undermining the natural resource base' (Scoones 1998:5). Similar to the access model, the framework supports the idea that political and social processes influence the distribution of, and access to, resources used to create livelihoods. He classifies such resources into four types of capital assets: natural (natural resources); economic (infrastructure, production equipment and technologies) or financial (cash, credit, savings); human (skills, knowledge, labor), and social (networks) capital (Scoones 1998).

Figure 3 presents the analytical framework of the study. The variables in boxes are the factors which influence farm households' vulnerability - their ability to absorb the shocks and recover in the event of the hazard (hexagon). The impacts and adaptive strategies (ovals) result when livelihoods are affected by the hazard. 
Vulnerability of farm households to impacts of the abaca bunchy top disease

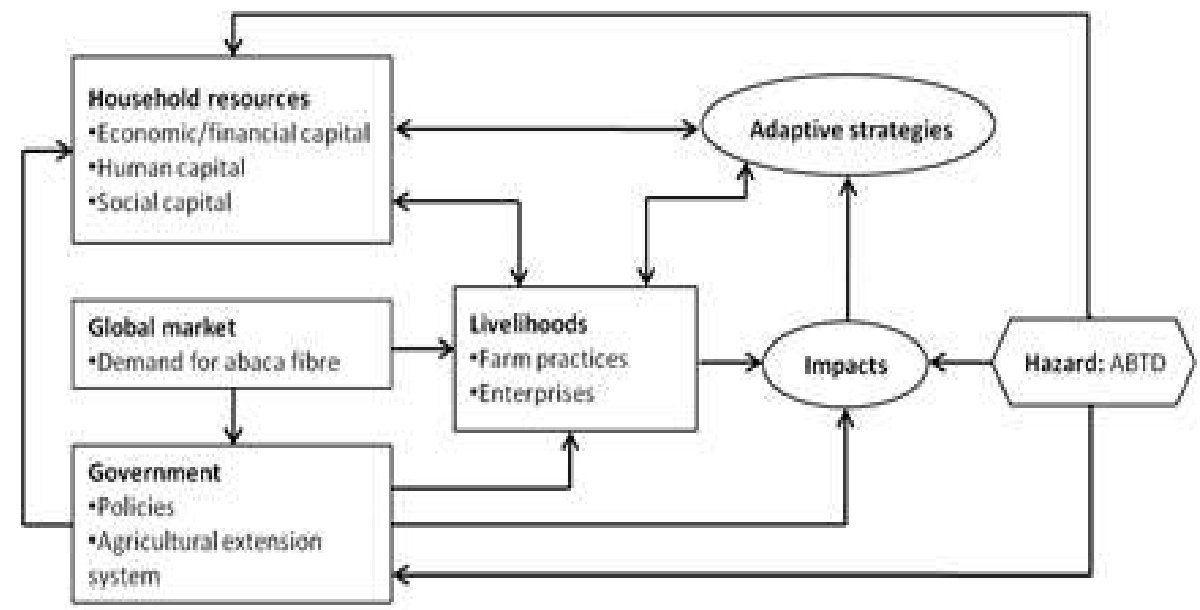

Figure 3. Analytical framework adapted from Blaikie et al $(1994)$ and Scoones $(1998,2009)$

In understanding access to resources by farm households in Brgy. Pinamonoan the influence of government policies and programs, particularly the agricultural extension system which directly deals with and assists farmers in their production, and the influence of the global market and the government through their influence on farm practices must be considered. The resources considered include only the economic/financial, human, and social capitals as these are deemed most relevant in the context of the study. The resources available to farm households determine the kinds of livelihood strategies in which they engage. These livelihoods are also affected by the global market and the government through their influence on farm practices. The livelihoods (capabilities, resources and activities) of these farm households may in turn influence their vulnerability to the hazard. The hazard dealt with in this study is the abaca bunchy top disease which has caused severe damage to abaca farms in the Philippines.

The relationships between some of the variables are two-way in that they mutually influence each other. While resources determine livelihoods, livelihoods also influence households' access to resources and assets. Resources influence the kind of coping and adaptive strategies and these strategies in turn increase, decrease or maintain households' resources. Livelihoods also influence the kind of coping and adaptive strategies employed and these strategies bring about changes in households' livelihoods.

This also shows that a hazard affects government policies and programs and household resources, which could intensify households' vulnerability. In this study, government actions also contributed to the extent of the impacts experienced by households in the occurrence of ABTD. 


\section{RESULTS AND DISCUSSION}

Impacts of the abaca bunchy top disease and adaptive strategies of farm households

Farm households in Brgy. Pinamonoan experienced the loss of income when their crops were destroyed by the combination of ABTD and inappropriate use of herbicides. According to informants, a government agency conducted eradication activities which involved chemical pesticides: insecticides to kill the vector and herbicides for infected crops. Informants recall that there were two herbicides used: Roundup and 2, 4-D (2, 4-2, 4-Dichlorophenoxyacetic acid). Although seminars were conducted to demonstrate the use of these pesticides to farmers, it was mainly women who attended the seminars as their husbands continued work on the family farms. Some informants claimed that the women did not correctly relay the information to their husbands, while other accounts state that the pesticides were left for distribution with some villagers without proper instructions on their use and effects. The term 'medicine' was inappropriately used by technicians to refer to the pesticides. Farmers, thinking that the chemicals were 'medicine', applied the herbicides even to healthy crops in the belief that it would prevent them from getting infected. Instead, healthy crops died along with the infected ones, leaving farmers disappointed and angry. This had secondary impacts to businesses in and near the village. The loss of income decreased the quantity of households' consumption of goods and their capacity to pay, therefore decreasing the profit of stores which sell these.

The loss of income also led to flow-on impacts on households' food security, education, health and even psychosocial well-being. However, small landowning households were more affected than those with medium-sized farms. Households with small farms generally had to switch to root crops as their staple food while those with medium-sized farms could still afford rice, although in smaller quantities. Children and young people of small landowning households had to stop schooling because of income loss. Those with illnesses among households were also disadvantaged because they could not afford to immediately buy medicine when the need arose.

These changes brought about by the loss of crops and decline in income prompted farm households to look for ways to cope. The severity of the disease led to government action to prevent its further spread by eradicating the vector and infected crops. Government agencies also supported the farm households through livelihood assistance programs. With the loss of their livelihood and decline in income, farm households became involved with financial institutions/organizations which provided them with loans.

\footnotetext{
${ }^{2}$ Impacts of ABTD and farm households' adaptive strategies are discussed in full in the article Social impacts of the abaca bunchy top disease and adaptive strategies of farm households: a case in Leyte, Philippines (Nuñez JMC. 2013. Annals of Tropical Research, 35(2):69-87)
} 
Vulnerability of farm households to impacts of the abaca bunchy top disease

Generally, one strategy alone could not meet their daily needs. Switching to coconut provided a sure harvest as there was no disease affecting these crops in the village at the time. However, income from copra was not always enough to sustain households until the next harvest. Mixed cropping provided food and added to income, but apparently this was still not enough for some households. Although wage labor added to household income, it was not sufficient as a sole livelihood strategy because the earnings of a laborer was low and work opportunities were not regularly available in the village. It was particularly disadvantageous for children who had to work instead of attending school.

Migration was a practical strategy as migrants were able to find jobs and send money back to their families in the village. However, this has negative repercussions in that it contributes to overpopulation in urban areas. Credits and loans met the basic expenses of some households, but they were burdened with weekly repayments. Mortgaging of land addressed great financial needs, but it decreased the productivity of households. Small enterprises also added to income but these were not very lucrative. The most profitable enterprise was one that required a significant financial capital which was not accessible to economically challenged households.

The livelihood strategies employed to cope with ABTD differed from household to household. Small landowning households generally engaged in wage labor, credits and loans and small enterprises to earn income. Those with medium-sized farms were generally independent of loans and one such household was able to engage in a profitable new enterprise. While these strategies provided new income sources, some of them were unsustainable and may have disadvantaged households in the long term.

\section{Farm households' access profile}

A household's access profile encompasses the resources and assets which they can access to make a living and mobilize in times of disaster. As such, assets can provide an indication of the economic status of farm households. Although asset poverty is not synonymous with vulnerability, households which are better off are more likely to recover from exposure to risk (Blaikie et al 1994). This study focused on three of the four types of capital assets: economic/financial, human and social (Scoones 1998, 2009).

\section{Economic/financial capital}

Access to land is important in an agrarian economy as this fundamental productive resource shapes a farm household's vulnerability and capacity to cope in times of stress (Adger et al 2001). Informants had a mixed pattern of land ownership but they all owned land. Almost all of the informants were ownercultivators. Some were tenants but they all owned a piece of land. One informant hired laborers to work on her farm. The acquisition of land was by purchase and inheritance. According to some informants, the families who settled first in the village got the bulk of the land near it. Those who came afterwards could only find land to farm in the mountains very far from the village, which were actually part of the next municipality (Sogod). 
The majority of informants (81.25\%) were small landowners, owning tracts of land less than 10 ha. Only a few (18.75\%) had medium-sized blocks of land of over 10ha. This is comparable with the distribution of land holdings in the Philippines, where almost $98 \%$ of land holders are smallholders (NSO 2002).

Land ownership determined the magnitude of farm households' income from abaca before ABTD. Thus, the majority of small land owners also had low incomes. These income estimates, however, are only indicative of farm households' annual income from abaca as they did not take into account many other factors that could affect the productivity of farms. Table 1 shows the informants' extent of land ownership in Brgy. Pinamonoan in relation to their income classification. There were medium landowners whose income from abaca was low, while some small landowners had higher incomes than these medium landowners. It is worth noting, however, that two of these small landowners had farm sizes close to 10ha (9ha and 9.75ha).

Table 1. Land ownership and annual income from abaca among informants in Brgy. Pinamnnnan hefore $\triangle R T \cap$

\begin{tabular}{lcc}
\hline \multicolumn{1}{c}{ Income class } & Middle & Low \\
Land ownership & 3 & 23 \\
Small landowner & & \\
Medium landowner & 3 & 3 \\
\hline
\end{tabular}

Note: Low income class: <P25, 283 (US\$5,843.79) per year; middle income class: P251,283-2,045,280 (US\$5,843-47,564.65) per year (National Statistical Coordination Board, 2007)

The influence of land ownership on the acquisition of other assets is illustrated by comparing the cases of Marilyn and Edna. Marilyn, 56, was a businesswoman, who together with her husband, owned 20ha of land. This was planted with abaca before the incidence of ABTD. They had an annual income from abaca of more than P1.6 million (US\$37 209). Because of this level of production, they had acquired a truck to transport abaca fiber and five fiber stripping machines. They had one son, raised two nephews and had a house help. They lived in a two-storey house made of durable materials (hollow blocks and galvanized iron) and owned a car and two motorcycles. They also owned a village store. On the other hand, Edna, 34, and her husband owned 1 ha land and earned about P40 000 (US\$930) a year from abaca. Her husband also worked as a paid laborer and they had other crops, but their main income was from abaca. They lived in a rented house with their seven children and had no other assets.

\footnotetext{
${ }^{3}$ This was computed from the data given by informants on the number of kilograms they harvested, the number of times they harvested per year, and the highest price they have received for their fiber. For those who did not give these data (according to them, they cannot remember), estimates were used based on the area of land they planted with abaca. One hectare ideally yields $1-1.5$ tonnes $(1000-1500 \mathrm{~kg})$ of fiber per harvest with three to four harvests per year. A minimum of 1 ton or $1000 \mathrm{~kg}$ and three harvests per year was used. The price most commonly quoted by respondents which is $\mathrm{P} 20 / \mathrm{kg}$ was used in the equation: area planted to abaca (in ha) $\mathrm{x}$ $1,000 \mathrm{~kg} \times \mathrm{P} 20 / \mathrm{kg} \times 3$ harvests per year $=$ annual income.
} 
Vulnerability of farm households to impacts of the abaca bunchy top disease

Access to land and other resources gives households more opportunities to secure a livelihood under adverse conditions. Those with limited access, on the other hand, have more limited options, making them less resilient in the face of adversity (Blaikie et al 1994). When ABTD wiped out her crops, Marilyn had the financial resources to buy abaca planting materials and hire laborers to reestablish her farm. When these crops also got infected, she switched to coconut. Although her sari-sari store also suffered losses, it was still in business.

For Edna and her household, the loss of their crops to ABTD had a severe impact. They had to plant banana and root crops for subsistence and her husband had less paid work in other farms, which were also infected by ABTD. This further reduced their income. Earnings from their own crops, which amounted to about $\mathrm{P} 1,000$ (US\$23.25) per week, were just enough to cover their daily expenses and repay debts. They could not fully re-establish their farm because their only source of planting materials was their own farm.

Complexity and diversity in livelihood systems increases their security and reduces vulnerability by adding to the sources of food, income and other resources (Chambers 2003 in Gibson et al 2010). Although abaca was their primary crop, some farmers had well established coconut farms before the incidence of ABTD, and so they still had a reliable income source even though their abaca was lost.

\section{Human capital}

Education enables access to skilled work opportunities, which provide higher incomes than jobs requiring only physical labor (Blaikie et al 1994). Therefore, with lower levels of education, informants also reduce their opportunity to access such skilled work. Moreover, livelihoods which entail more physical work increase the risk of physical injury (Blaikie et al 1994). An example is one informant's son who did farm work because he could not afford to go to school. He got injured when a large piece of wood he was carrying fell and broke his foot. This injury entailed extra medical expenses which would have taken away a considerable amount from the household's already limited income, if not for the assistance of relatives who contributed to pay for the expenses.

Interviews found that education was not a high priority among households especially before the incidence of ABTD when their farms were productive. This is reflective of the general situation in the Eastern Visayas (where Mahaplag is situated) where only $15 \%$ of its population finish high school and only $7.66 \%$ have a university degree (NSO 2003). There were informants who had the capacity to get a college degree but stopped schooling after graduating from high school and got married instead. Figure 1 shows that the number of informants decreases with each increasing level of education.

The important role of education in earning income is best exemplified by the case of Sulpicio, 73 , who used to be a farmer until he was diagnosed with a lung problem in 2010. He has a daughter who works as a teacher. Her salary is currently the household's major source of income. His daughter's education qualified her to access a work opportunity that provided regular and sufficient income for the household. 
Social capital is the 'networks, norms and trust that facilitate coordination and cooperation for mutual benefit' (Putnam 1993:2). There were many ways in which support networks influenced the adaptive strategies employed by households. Household members who migrated to look for job opportunities helped others who followed find jobs and places to live in. They also sent remittances, which informants said were important contributions to the household income, particularly in covering unexpected medical expenses. Some farmers were able to borrow money from copra and fiber buyers with whom they had been doing business. In addition, the friendship between particular people in the village and technicians/extension workers led to the unequal distribution of government support with these people accessing more benefits than others.

However, in farming matters, there was little to no cooperation between households in the village. According to informants, each household worked hard on their own. There were some who said that they used to get planting materials from their neighbors but generally, farm households carried out their work without assistance from other households. Thus even when their crops were infected, they worked individually to eradicate infected crops and re-plant.

The disease outbreak also impacted social capital. Some barangay officials, for instance, stated that the loss of crops limited their ability to lend money. Exploitative relationships also surfaced in the form of loan sharks who lent money but demanded high interest rates, thus increasing the vulnerability of the poor who borrowed from them. The occurrence of thefts in farms eroded the trust among the people in the village, as those who committed thefts were themselves from the village, further reducing social capital.

These cases illustrate how social capital influenced responses to ABTD, but also how it broke down under adverse conditions when the scarcity of resources strained cooperation and reciprocity (Moser 1996, Blaikie et al 1994). The breakdown of social capital further reduced the access of households to resources such as informal loans, which was an important coping strategy. These informal loans covered expenses in excess to what households had the capacity to shoulder and required no interest compared to other loans. The breakdown of social capital also prevented households from joining activities that could benefit the entire village, such as mass disease eradication activities, as each household was busy with its own livelihood strategy.

\section{Global market, policies and the agricultural extension system}

Abaca is a traditional agricultural crop of the Philippines. The fact that the country is the major global supplier of abaca fiber signifies its importance as an export commodity (Philippine Council for Agriculture, Aquatic and Natural Resources Research Development 2003). The global demand for abaca fiber led to its cash cropping. It was both promoted by the government (through legislation and the establishment of agencies responsible for the abaca industry) and deemed profitable by farmers. A sole focus on cash crops, while profitable under ideal conditions, increases vulnerability of farm households. First, monocropping makes crops more susceptible to pests and diseases (Bareja 2010). Second, there 
Vulnerability of farm households to impacts of the abaca bunchy top disease

are no other crops to provide a safety net when income declines due to crop losses. Although official recommendations stipulate the intercropping of abaca (as it grows well in $50 \%$ shade), in Brgy. Pinamonoan abaca was mainly grown as a monocrop.

Although the industry is constrained by problems as it faces increasing competition from other countries, the government wants to maintain the Philippines' dominance as a global producer. The top buyers of abaca fiber from the country are the United Kingdom and Japan. The demand is increasing with the efforts of Western countries to 'go green' with an associated preference for natural fibers. New applications for abaca fiber are opening such as the replacement of fiberglass in composites in cars and coniferous wood pulp. Thus, the government is supporting the development of disease-resistant varieties, eradication of pests and disease and the rehabilitation and expansion of farms (Philippine Fiber Industry Development Authority nd in National Abaca Research Center 2008, PCAARRD 2003).

In these programs, abaca farmers are seen simply as adopters of technologies who should be assisted to increase their production and profit from abaca. This stance of the agricultural extension system of the country reflects its top-down approach in dealing with farmers. It is generally still operating on the 'yeoman farmer fallacy,' or 'the belief that equity can and should be achieved mainly by supporting farmers as producers' (Christoplos and Farrington 2004:32). It has been generalized that abaca farmers are poor and that technology is the primary means to help them out of poverty (PCAARRD 2003). However, this assumption is flawed because it is farmers' poverty that hinders them from accessing technology.

Past government interventions in Brgy. Pinamonoan are instructive for the development of government programs. Inputs were poured in with the expectation that farm households would be able to capitalize on these and re-establish profitable livelihoods. Free abaca planting materials were given out; however, these produced low quality fiber. Low income farmers could not afford planting materials, especially good quality, tissue-cultured plantlets. A number of households were able to benefit from the vegetable program. However, this did not contribute to a sustainable livelihood throughout the year as vegetables only grew well during the summer and rotted during the rainy season. Financial capital was also provided by the government, but this did not always achieve its goal because households used the money to meet their basic needs and not as capital for microenterprises. These interventions might have contributed to meeting some basic and immediate needs, but failed to reduce households' vulnerability in the long term as they were unsustainable and did not contribute to secure livelihoods in the long term.

Ideally, extension should move its direction from asset accumulation to livelihoods risk mitigation by spreading knowledge on livelihoods to help people make better choices and carry these out (Christoplos \& Farrington 2004). Instead of focusing primarily on increasing productivity through technology transfer, extension should also help rural people gain knowledge that could help them pursue diverse agricultural and non-agricultural livelihoods. This knowledge could include information on the risks involved in agricultural livelihoods, livelihood diversification and investment of finances as safety nets. 
The capacity of those in the government is a major constraint in government initiatives. Information drives on disease identification and management were only conducted through the extension system when the disease outbreak was already severe. The widespread occurrence of ABTD had been documented in the early 1900s, yet it is evident that this had not been taken into account in programs concerning abaca. Knowledge of disease identification and control primarily belonged to the scientists. Even the agricultural technicians who were supposed to assist farmers in their livelihoods did not know about this initially. When the disease was identified, it was already spreading fast in the farms. This lack of knowledge on the part of both the technicians and farmers meant that early detection and prevention of the disease was impossible. Had farmers known what the disease was like and how to control it, the extent of its damage could have been contained. This illustrates that knowledge is an important resource in maintaining livelihoods and responding to hazards (Blaikie et al 1994).

Secondly, and most importantly, the extension system failed to properly implement its disease eradication program, and this resulted in even greater damage to crops. Instead of controlling the disease, the inappropriate use of herbicides compounded the damage caused by ABTD. Both healthy and infected crops were wiped out by the herbicide in a matter of days. This resulted in farmers' anger and distrust towards the agencies involved and the government in general, making it more difficult to convince them to undertake further disease control measures.

Technocracy, or the emphasis on technical skills as a basis for development (Barr 2005), is evident in the policies concerning the abaca industry in the country. The Abaca and Other Fibers Development Program Act (Republic Act No. 4967) was promulgated to maintain the country's dominance in global abaca production by increasing production (Government of the Philippines 1967). The law provides for the financial and human resources for research, improvement of production, expansion and rehabilitation of farms and development of new industries from abaca and other fibers. The focus is on technology transfer for the improvement of the industry and not on the livelihood security of farm households, perhaps with the assumption that increasing productivity will lead to the improvement of the lives of farm households. While good production of cash crops does contribute to the well-being of households, policies and extension failed to educate farmers about the risks of over-reliance on such crops.

The damage of ABTD in Leyte prompted the provincial government to issue rules on the implementation of abaca disease management. These rules primarily regulated the transport of abaca and other Musa plants and plant parts and required participation in eradication activities supervised by the government agencies concerned. As an incentive for participation in eradication activities, the government provided inputs for an alternative livelihood 'such as but not limited to vegetable production' (Provincial Local Government Unit of Leyte 2006:7).

While the prohibition of the transport of abaca and its plant parts was essential in controlling the spread of the disease, it had negative outcomes for farm households. First, they were unable to find planting materials. Second, gathering umbac, an important income source, had to stop because it facilitated the spread of the insect vector, thus taking away another income source. These factors combined to reduce the ability of abaca farmers to cope successfully with 
Vulnerability of farm households to impacts of the abaca bunchy top disease

the disease outbreak. Those households which had less income sources and less opportunities to diversify livelihoods were most affected. While most of them still expressed an interest in planting abaca, the obstacles they faced eventually caused many of them to give up. This in turn had negative implications for the country's efforts to improve its abaca industry.

\section{Vulnerability amongst abaca farmers}

In summary, there was not one farm in the village that escaped ABTD infection. However, some households were more affected than others. Access to resources determined how farm households absorbed the shock and recovered from it. Households who had significant assets were able to shift to other crops or enterprises. Those with well-established coconut trees were less affected by the loss of abaca because they had an alternative reliable source of income. Households with access to people with resources and who could provide assistance were also more likely to cope. The most affected in the village were the households who, even before the disease, had limited resources, both in terms of material assets and social support networks.

Within households, it was difficult to determine who was most affected because different members each carried a burden as an effect of crop loss. The men were burdened with more physical labor and a reported heavy sense of responsibility to put food on the table. Women had to perform additional tasks to earn an income aside from their usual household responsibilities. Children were deprived of educational opportunities and had to work instead.

While abaca production is a profitable livelihood, sole reliance on this can lead to disastrous results when a hazard, in this case ABTD, destroys this livelihood. Monocropping of abaca in Brgy. Pinamonoan was influenced by the high demand of abaca fiber globally. This global demand made abaca an important export commodity, hence government policies and programs were focused on increasing production and less on ensuring that the livelihoods of farm households engaged in abaca production were secure.

According to Blaikie et al (1994:58) 'vulnerability is a hypothetical and predictive term which can only be proved by observing the impact of the event when, and if, it occurs.' By analyzing the impacts of ABTD on farm households in Brgy. Pinamonoan, the instability of agriculture-based livelihoods and the limitations of the extension system at work are exposed. Unless something is done to improve the capacity of farmers and technicians to cope with the risks involved in agriculture-based livelihoods by providing information and facilitating access to resources, the situation in Brgy. Pinamonoan could repeat itself in other parts of the country.

\section{CONCLUSIONS}

This study points out the factors that increased the vulnerability of farm households to ABTD. First, their ability to absorb and recover from shocks was largely determined by their access to resources. Although all of the farms were infected with ABTD, the degree of impacts and responses of households differed. Households with medium-sized farms and social networks that is, more assets, 
were less affected by the loss of crops and were more likely to engage in other profitable enterprises than those with small farms and less social networks. The disease further reinforced social vulnerability in that it reduced the future assets available to households. An important implication is that rural communities responding to a disaster should be viewed not as a whole, uniform entity, but as stratified societies with households that have differing capacities to absorb and recover from shocks, according to their assets.

Secondly, this study highlighted how livelihood strategies, in this case an overreliance on abaca monoculture to satisfy the global demand for abaca fiber, contributed to ecological and socio-economic vulnerability. While the global demand for abaca fiber helps the national economy, securing farmers' livelihoods requires that abaca should be coupled with other livelihood strategies, rather than an undue emphasis on increasing abaca production.

Thirdly, this is a case study of how an ill-formed and poorly implemented government program could contribute to a disaster. It also highlighted the failures of the agricultural extension system in the area. This system's top-down, technocratic approaches did not take into account local capabilities and needs, nor address the vulnerability of farm households. Groups that are most vulnerable and in greater need of assistance are the ones who often get left out of government programs.

Disasters are not separate from everyday living (Blaikie et al 1994). With this realization, mitigating the effects of ABTD should not focus on disease eradication alone. By bringing attention to the factors that make farm households vulnerable to crop disease, this research highlights that reforms are needed in government policies and programs and that responses to crop diseases like ABTD need to target marginalized farm households in order to reduce their vulnerability in the long term.

\section{ACKNOWLEDGMENT}

The author is grateful to the National Abaca Research Center (NARC) for allowing her to use its vehicle during her fieldwork. This article is part of her master's research under the Endeavor Scholarships and Fellowships of the Australian government. 
Vulnerability of farm households to impacts of the abaca bunchy top disease

\section{REFERENCES}

Adger WN, Kelly PM \& Ninh NH (eds.). 2001. Living with environmental change: social vulnerability, adaptation and resilience in Vietnam. Routledge, Oxon.

Bareja BG. 2010. Cash crop farming is for profit. Accessed 25 May 2011 from http://www.cropsreview.com/ cash-crop-farming.html

Barr MD. 2005. Beyond technocracy: the culture of elite governance. In: Singapore LH. Loong (ed.). Griffith Asia Institute. Accessed 12 June 2011 from http://www. griffith.edu.au/_data/assets/pdf_file/0016/18232/regional-outlook-volume6.pdf

Blaikie P, Cannon T, Davis I \&Wisner B. 1994. At risk natural hazards, people's vulnerability, and disasters. Routledge, London.

Cannon T. 2000. Vulnerability analysis and disasters. In Parker DJ (ed), Floods. Routledge. Accessed 20 April 2011 fromwww.radixoline.org/resources/cannon -floods-chapter.doc

Christoplos I \& Farrington J (eds). 2004. Poverty, vulnerability, and agricultural extension: policy reforms in a globalizing world. Oxford University Press, New Delhi.

Clark GE, Moser SC, Ratick SJ, Dow K, Meyer WB, Emani S, Jin W, Kasperson JX, Kasperson RE \& Schwarz HE. 1998. Assessing the vulnerability of coastal communities to extreme storms: The case of Revere, MA, USA. Accessed 4 April 2011 from https://doi.org/ 10.1023/A:1009609710795

Corbett J. 1988. Famine and household coping strategies. World Development, 16(9):1099-1112. Accessed 16 May 2011 from http://archserve.id.ucsb.edu/cou rses/id-moodle/moodledata/261/Corbett_Coping.pdf

Ecological Farm And Resource Management Institute (ECOFARMI). 2011. Map of Brgy. Pinamonoan, Mahaplag, Leyte.

Food And Agriculture Organization Of The United Nations (FAO). 2003. Southland: a case study-based training exercise in policy analysis for the agricultural and rural sector. Accessed 10 June 2011 from http://www.fao.org/DOCREP/006/Y5137E/ y5137a07.htm

Gibson K, Cahill A \& Mckay D. 2010. Rethinking the dynamics of rural transformation: performing different rural pathways in a Philippine municipality. Accessed $16 \mathrm{Ma} 7$ 2011 from http://www.communityeconomies.org/site/assets/media/Gibson/Re thinking\%20rural\%20transformation\%202010.pdf

Government Of The Philippines. 1967. Republic Act No. 4967 or the Abaca \& Other Fibers Development Program. Accessed 3 May 2011 from http://www.chanrobl es.com/republicacts/republicactno4967.html

Manila Bulletin. 2003. Bunchy top disease wreaks havoc on abaca and banana. 13 June. Accessed 9 Octovber 2010 from http://findarticles.com/p/news-articles/ manila-bulletin/mi_7968/is_2003_June_13/bunchy-disease-wreaks-havoc-aba ca/ai_n33494385/

Moser CON. 1996. Confronting crisis: a comparative study of household responses to poverty and vulnerability in four urban communities, The World Bank, Washington, D.C.

National Abaca Research Center (NARC). 2008. Abaca industry situationer. NARC, Visayas State University.

National Statistical Coordination Board (NSCB) 2007. http://www.nscb.gov.ph/ headlines/StatsSpeak/2007/121007_rav_poverty.asp\#table4(accessed June $12,2011)$. 
National Statistics Office (NSO) 2000. Total population, household population and number of households by province, city, municipality and barangay: as of May 1, 2000. Accessed 13 May 2011 from http://www. census.gov.ph/census2000 /p083700.html

National Statistics Office (NSO) 2002. Philippines-agricultural census-main results. Accessed 11 June 2011 from http://www.fao.org/fileadmin/templat es/ess/documents/world_census_of_agriculture/countries_for_website/PHI LIPPINES_2002.pdf

National Statistics Office (NSO) 2003. Percent distribution of population 6 years old and over by age group, by highest educational attainment and region, Philippines:2003. Accessed 17 June 2011 from http://www.census.gov.ph/ data/sectordata/2003/fl03tabA.htm

Nuñez JMC. 2013. Social impacts of the abaca bunchy top disease and adaptive strategies of farm households: a case in Leyte, Philippines. Annals of Tropical Research 35(2):69-87.

Oliver-Smith A. 1996. Anthropological research on hazards and disasters. Annual Review of Anthropology 25:303-328.

Philippine Council for Agriculture, Forestry and Natural Resources Research and Development (PCAARRD). 2003. R and D status and directions (2000 and beyond). Accessed 4 May 2011 from http://maidon.pcarrd.dost.gov.ph/jooml a/resources/comm/randd/Abaca.pdf

Provincial Local Government Unit (PLGU) 2006, Rules and regulations governing the implementation of abaca disease management and industry development ordinance in the province of Leyte, Office of the Provincial Governor, Leyte, Philippines.

Putnam RD. 1993.The prosperous community: social capital and public life. Accessed 13 June 2011 from http://www.philia.ca/files/pdf/ProsperousCom munity.pdf

Scoones I. 1998. Sustainable rural livelihoods: a framework for analysis. IDS Working Paper 72.

Scoones I. 2009. Livelihoods perspectives and rural development. Journal of Peasant Studies, 36(1):171-196.

Vurro M, B Bonciani and G Vannacci. 2010. Emerging infectious diseases of crop plants in developing countries: impact on agriculture and socio-economic consequences. Food Security, 2:113132. Accessed 17 October 2010 from http://www.springerlink.com/content /q006261227838073/fulltext.pdf 